\title{
THE CORRECT NAME FOR THE WHITE-FLOWERED VARIANT OF DICTAMNUS ALBUS L. (RUTACEAE)
}

\author{
James COMPTON ${ }^{1}$, John AKEROYD ${ }^{2}$ \\ ${ }^{1}$ Spilsbury Farm, Tisbury Row, Tisbury, Salisbury SP3 6RU, UK \\ ${ }^{2}$ Caroline Cottage, The Dene, Hindon, Salisbury SP3 6EE, UK \\ e-mail: jamiecompton@madasafish.com
}

\begin{abstract}
In this paper we explore Linnaeus's use of the name Dictamnus albus L. (Purple Dittany, Burning Bush) which distinguished this species from Origanum dictamnus L. (Cretan Dittany) a labiate endemic to the island of Crete. Linnaeus's name for the species did not intend to reflect its flower colour but was based on the medicinal name for the white roots of the plant. Because Linnaeus's type specimen is based on plants with purple stems and purple-veined flowers, we publish here the name Dictamnus albus var. albiflos (Rchb.) J. Compton \& Akeroyd, comb. nov. for plants with white flowers. This feature distinguishes these plants from the more widespread typical variant frequently referred to, especially in the horticultural literature, as D. albus "var. purpureus", an invalid name. We also designate a neotype for var. albiflos and lectotypes for ten of the names within the synonymy of D. albus var. albus: Dictamnus albus var. bucharicus N.A.Winter, Dictamnus albus var. gynodynamicus Beck, Dictamnus angustifolius G.Don ex Sweet, Dictamnus fraxinella var. europaeus Fisch. \& C.A.Mey., Dictamnus fraxinella var. macrophylla Schur, Dictamnus gymnostylis Steven, Dictamnus himalayanus Royle, Dictamnus hispanicus Webb ex Willk., Dictamnus obtusiflorus W.D.J.Koch and Fraxinella dictamnus Moench.
\end{abstract}

Keywords: Dittany, nomenclature, neotype, lectotype, Linnaeus, Reichenbach

\section{Introduction}

Dictamnus albus L., Purple Dittany or Burning Bush (or the unpleasant name Gas Plant), has been known for many hundreds of years and has long been grown in European and North American gardens. The original "Dictamnus" or "Diptamnus", which was also known in Latin as "Tragium", was, however, recorded by Dioscorides and Theophrastus and shown in early illustrations to be a species of Origanum (Cretan Dittany, O. dictamnus L.), a labiate endemic to the island of Crete. Dictamnus albus is an erect, herbaceous member of the rue family (Rutaceae), somewhat woody at the base, with pinnate leaves and stout showy inflorescences up to a metre tall bearing large, zygomorphic flowers which have streaked, purplish-pink, pink or white petals. The whole plant is clothed in citrusy aromatic glandular hairs full of inflammable volatile oils which have led to the legend that the vapours emitted from the plant could spontaneously ignite in extreme heat on a still day, hence "Burning Bush". Its more familiar English name "Dittany" is merely a corruption of the Latin Dictamnus, a name that may have originated from Mount Dikte [Dhíkti] in eastern Crete (Stearn 1993: 119). The species Dictamnus albus is regarded by many authors to be the only one in the genus Dictamnus L. (Townsend 1967: 506; 1968: 229; Mabberley 2017: 292). It is known to have a huge natural distribution from south-east Spain across south and south-central Europe, west and central Asia 
extending into Siberia, Korea and northern China. Owing to its vast geographical range numerous taxonomists over the years have attempted to distinguish variants of this plant at specific and lower ranks in different regions of Eurasia (see Synonymic Conspectus below). The characters used are now believed to be plastic and unreliable (see e.g. Townsend 1968) and do not correlate with distribution. Such characters included: width of leaflets; length of the claw on petals; length of the ovary stipe; hairy or glabrous ovaries; winged or more or less wingless leaf rachis; and length of the beak on fruiting capsules.

Both of us had long been aware that the name "var. purpureus" frequently attached to $D$. albus, especially in the horticultural literature and nursery catalogues and websites, was invariably used loosely and without reference to any published authority. Search for the correct citation led through centuries of somewhat convoluted history of the nomenclature of Linnaeus's species, its more widespread typical purplish-flowered variant and the white-flowered variant that is rare in the wild. It is this white variant that apparently lacks a valid name.

\section{Discussion of Linnaeus's type}

Linnaeus described Dictamnus albus L. in his Species Plantarum as originating from Germany, France and Italy (Linnaeus 1753: 383). He listed three of his own publications (Linnaeus 1738; 1748; 1749), a reference to Adriaan van Royen (1740), another to François Boissier de Sauvages (1751) and two much earlier works; Casper Bauhin (1623) and Paul de Reneaulme (1611). Bauhin's reference to Fraxinella meaning "little Fraxinus or ash" (hence Fraxinelle in French and Frăsinel in Romanian) is to the pinnate, ash-like leaves of this, his fifth "species" Dictamnus albus vulgo, sive Fraxinella (Bauhin 1623: 222). This name was used in a generic sense by Reneaulme, whose illustration showed flowers which were clearly marked with dark veins radiating outwards from the base of each petal (Reneaulme 1611: 121). The illustration in Reneaulme leaves no room for doubt as to its identity. Furthermore, in his description Reneaulme distinguished the "fraxinella" from the Cretan Origanum plants following earlier herbals. One such herbal was that of Jean Ruel (1474-1537) who edited several editions of the pharmacopea De Materia Medica of Pedanius Dioscorides. Ruel described the Cretan dittany under the heading "Dictamnum Cap. 31" as "Dictamnum Cretensis herba est, acris, lanis, Pulegio similis" (Ruel 1552: 357). He also provided a description of purple dittany "Dictamnus Italica, quam albam vocat, et quidam a fraxini foliorum similitudine, frassinello, flores habet flagrantissimi odoris", thereby unequivocally separating the two different species, and alluded to the ash-like leaves and strong fragrance of the latter.

In another of the early herbals, Rembert Dodoen's Cruijdeboeck, there is a well executed illustration under the name "van valsch Diptamum" which once again leaves no room for doubt as to its identity; again the flowers are dark-streaked (Dodoens 1563: 290). The illustration and text are separated in the latter's work from the Cretan Dictamnus which has its own illustration of what is identifiable as Origanum dictamnus (Dodoens 1563: 230).

Reneaulme also alluded to the different flower colour that can occur in the species. He added the statement "Illius enim flos aut purpureus, aut candidus" within his description, which in his context meant - "There [i.e. in Greece] certainly the flowers may be purple, or white"(Reneaulme 1611: 122).

The specific epithet albus = white has caused some confusion over the centuries because white-flowered plants of this species are extremely rare in the wild. Why this plant has been 
referred to as albus by successive authors is explained by Clusius (1601: 100) who stated "Olet etiam hircum vulgo Fraxinella appellata, cujus radix Dictami albi nomine in officinis nota est et usurpatur" [That called Fraxinella also generally smells goatish, of which the root named white Dictamne is marked and used in apothecaries' shops]. He added "Crescit et in Francofordiano saltu, in quo aliquot plantae repertae niveo flore praeditae" [It occurs also in woodland glades around Frankfurt(-am-Main), where some plants are found with white flowers]. The reference to Clusius is to be found in Linnaeus's annotation on the specimens which he collected from plants grown in George Clifford's garden at de Hartekamp near Haarlem in the Netherlands while working there between 1735 and 1737.

Streaked venation can clearly be seen on the petals of the lectotype specimen of Dictamnus albus which Linnaeus collected at de Hartekamp. This specimen was selected by Nair in Jarvis et al., Regnum Veg. 127: 42 (1993), overturning an earlier attempted typification (LINN 536.1) by Townsend in Rechinger, Fl. Iranica 36: 1 (1966), which was not original material. The Lectotype can be viewed by entering Dictamnus in the database for the Natural History Museum's collections in London (BM): https://www.nhm.ac.uk/our-science/data/linnaeantypification/search/index.dsml

Linnaeus's annotated label on the Clifford Herbarium specimen included Bauhin's polynomial "Dictamnus albus vulgo, sive Fraxinella" (Bauhin 1623: 222), but it also included a reference to Clusius's illustration and description of the plant he titled Fraxinella (Clusius 1601: 99). Linnaeus added, possibly later, his own binomial Dictamnus albus, the name which he used in his Species Plantarum (Linnaeus 1753: 383). There is another collection in the Natural History Museum, London (BM) holdings that Linnaeus made from the Clifford garden with the annotation "Fraxinella Clusii, Dictamnus albus" (BM-000558739). He was, however, also aware that there were both white- and purple-flowered plants of this species (Figs 1-2). Two further specimens in BM that Linnaeus collected from Clifford's garden both have white flowers and have the annotations in his hand "Fraxinella niveo flore Dictamnus albus" and "Fraxinella niveo flore Clusius Hist. 100 Dictamnus albus" on them (BM-000558740 and BM-000558741). The latter specimen we have chosen as the nomenclatural type for our new name for this whiteflowered variant. Moreover, within Linnaeus's references, Reneaulme (1611: 122) for example, based his description largely on plants that had purple or rose colouration on the stems and flowers, but he also cited white-flowered plants "Candido flore mihi illusit in monte qui vulgo ventosus dicitur" [With a white flower arrayed to me on the mountain which is widely called Ventoux (Mont Ventoux in dept. Vaucluse, southern France)]. Linnaeus (1738: 161) also included a reference to two flower colour varieties from Tournefort (1700: 430) " $\alpha$ Fraxinella niveo flore. Tournef. Inst. 430" and " $\beta$ Fraxinella purpurea major multiflora Tournef."

\section{Nomenclatural discussion}

In his protologue of Dictamnus albus in Species Plantarum (Linnaeus 1753: 383), Linnaeus did not indicate any infra-specific variation by the use of symbols such as $\alpha$ and $\beta$. Such symbols, which, when used consistently and accompanied by an epithet, are regarded as botanical varieties, he employed to distinguish minor levels of variation that might include flower colour, as in his account of Ruta graveolens on the same page. We can infer therefore that when he made his choice of epithet, he intended the name to encompass all flower colour variants. The earliest post-Linnaean attempt to distinguish plants by flower colour was by 
Persoon (1805: 464) who referred to Dictamnus fraxinella " $\alpha$ albus. $\beta$ purpureus".

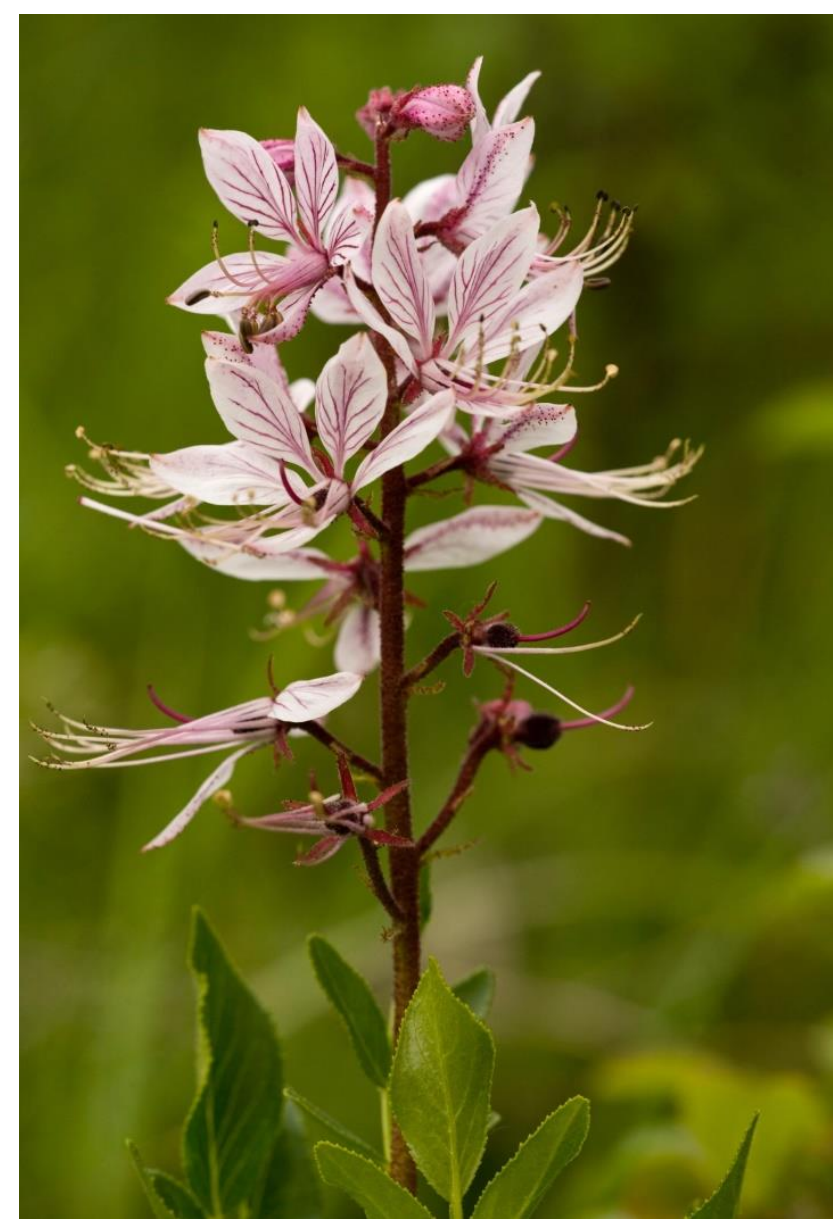

Fig. 1: Dictamnus albus L. var. albus, photographed in Transylvania (photo: Bob Gibbons)

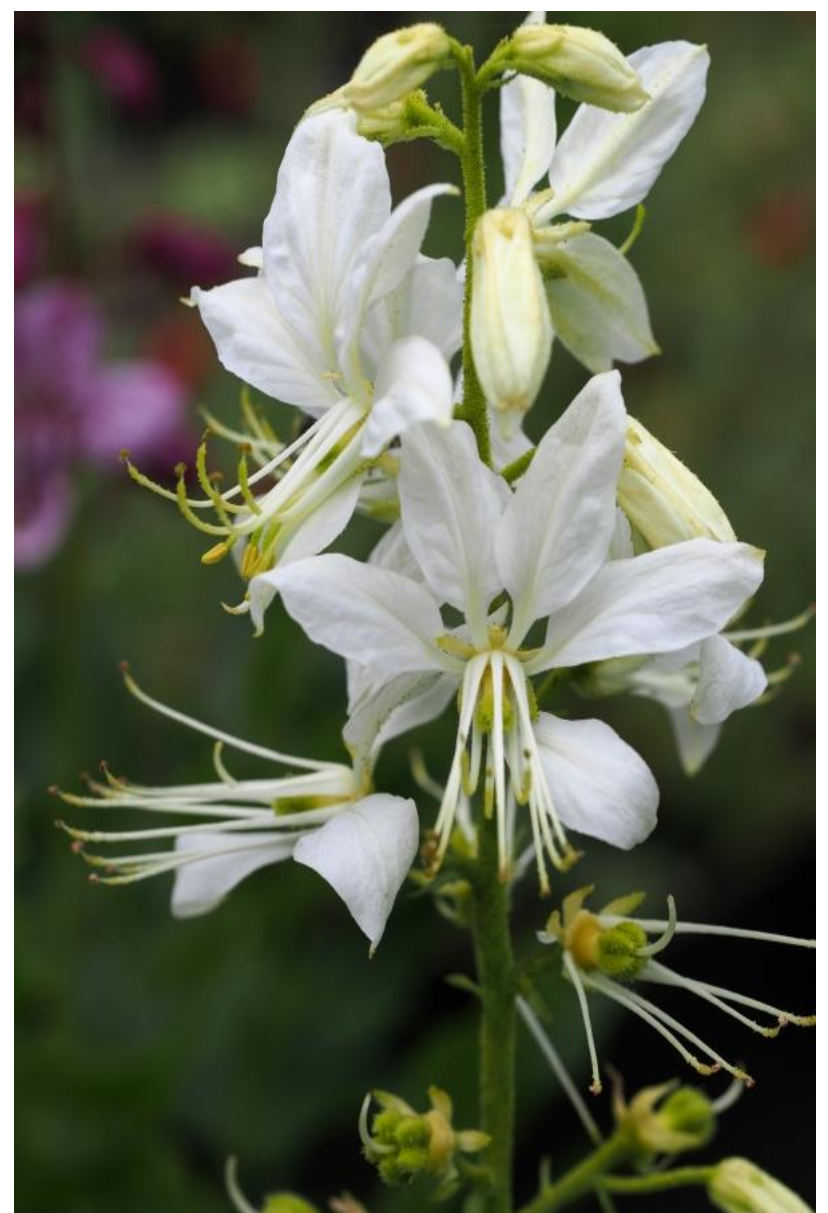

Fig. 2: Dictamnus albus L. var. albiflos (Rchb.) J.

Compton \& Akeroyd (photo: Hardy's Cottage Garden Plants, UK)

The protologue in Persoon (1805: 464) is:

1040. DICTAMNUS. Cal. 5-phyllus. Petala 5, patula. Filamenta punctis glandululosis adspersa. Caps. 5, coalitæ.

1. Fraxinella. $\alpha$ albus. $\beta$ purpureus. Lam. ill. t. 344. Fraxin. Reneal, spec. 122. t. 121. Hab. in Germania, Gallia, Italia, Flores utplurimum purpurei. 니.

Persoon did not mention Linnaeus directly in his species description of Dictamnus fraxinella Pers. but there is a tenuous indirect link to Linnaeus's use of the epithet 'albus' in that, in his Praefatio (Persoon 1805: vi), Persoon specifically alluded to his use of Willdenow's descriptions (Willdenow 1799) throughout his work (and he followed too Linnaeus's geographical information). The account of Dictamnus in the Willdenow edition of Linnaeus's Species Plantarum is almost the same as in the original (Linnaeus 1753), the genus described with the single species, D. albus (Willd. Sp. Pl. 2(1): 541 (1799)) and with only some additional references. With respect to "Dictamnus fraxinella $\alpha$ albus", Persoon could possibly have fulfilled 
the requirements for valid publication of Dictamnus fraxinella var. albus (L.) Pers. under Art. 41.3 of the International Code of Nomenclature (Turland et al. 2018) which requires that there is at least an indirect reference to a basionym for valid publication of the name (N. Turland pers. comm.; J. McNeill pers. comm.). In this case the basionym in question would be Dictamnus albus L. However this is tenuous at best and, although it would mean that D. fraxinella Pers. and D. fraxinella var. albus (L.) Pers. were validly published names, the former would be a nomenclaturally superfluous and hence illegitimate replacement for D. albus L., automatically homotypic with that name under Art. 7.5, and as 'albus' is the autonymic epithet under the correct name for the species (Art. 26.1), its publication as a varietal epithet under D. fraxinella has no significance (Art. 11.6). There is no description associated with either varietal epithet and so D. fraxinella "var. purpureus" would not, in any case, have been validly published (J. McNeill; J. Wiersema pers. comm.).

The name Dictamnus fraxinella Link was, however, unquestionably validly published by Heinrich Friedrich Link (Enum. Hort. Berol. Alt. 1: 398 (1821)) as a separate species from Dictamnus albus L. Link based his diagnostic differences on whether the leaf rachis was winged or not, leaflet shape and size and flower colour, with D. albus L. having a winged rachis, larger leaflets and a white flower and D. fraxinella Link without a margined rachis, smaller leaflets and a "red" flower (Link 1821: 712).

De Candolle (1824: 712) attributed the name Dictamnus fraxinella to Persoon (1805: 464) but in his description of $D$. fraxinella var. purpurea he attributed the variety to his having seen living plants and to Link's species Dictamnus fraxinella. The two varieties, both with reference to Link, are treated as follows:

“ $\alpha$ purpurea, petiolo obscure marginato, petalis pallide purpureis venis intense rubris striatis. D. Fraxinella Link enum. 1 p. 398. (v.v.)"

" $\beta$ alba, petiolo vix evidentius marginato, petalis albis. D. albus Link 1.c. (v.v)."

Both Dictamnus fraxinella var. albus DC and Dictamnus fraxinella var. purpureus DC are validly published. Although de Candolle attributed $D$. fraxinella to Persoon, if Persoon did not validly publish the name, de Candolle's use would be a validation in the same sense (and with the same illegitimacy) as that of Persoon (and not in the sense of Link) as de Candolle included D. albus L. as a synonym of his D. fraxinella (J.McNeill pers. comm.). Neither name would be available for transfer to Dictamnus albus L. because according to the type specimen, which has flowers with distinct purple venation, Dictamnus fraxinella var. purpureus DC would be a synonym of Dictamnus albus var. albus according to Art. 26.1 of the Code (Turland et al 2018).

Two further names have been published to accommodate the white-flowered variant of Dictamnus albus. First, Ludwig Reichenbach published the name "Dictamnus fraxinella Pers." var. albiflos Rchb., Fl. Germ. excurs. 2(2): 767 (1832), with the description "petiolo extrorsum alato, petalis albis". Although Reichenbach attached the variety to Persoon's illegitimate species name, the varietal name is still legitimate and may be used as the basionym of another combination (J. Wiersema pers. comm.) - see Art. 55.2 (Turland et al. 2018).

Thirteen years later Gussone published Dictamnus albus var. leucopetalus on page 721 of "Index locupletissimus Genera, Species, Varietates et Synonima omnia Florae Siculae complectens" to Fl. Sicul. Syn. 2 (1844-45). The title of the Index makes clear that it is more 
than just a reference to the pages of the two volumes. While "D. Fraxinella" is a synonym, "leucopetalus" and "purpureus" are accepted epithets of the varieties of D. albus, without any mention of the "a. albus" that actually appeared on p. 463 of vol. 1 of that work, so it is reasonable to assume that the "petalis albis" on p. 463 is a validating description for D. Albus var. Leucopetalus ('a.') shown in vol. 2: 721 (J. McNeill pers. comm.).

However, although the varietal name is validly published and is attached to the correct species, it contravenes the rule of priority. At the rank of variety Dictamnus fraxinella var. albiflos Rchb. has priority under Art. 11.4 (Turland et al. 2017).

We feel there is a need to recognize the white-flowered variant under the correct and earliest validly published name and therefore make the new combination here as Dictamnus albus var. albiflos (Rchb.) J.Compton \& Akeroyd, while at that rank the purple-flowered variant is Dictamnus albus var. albus.

Key to the two varieties of Dictamnus albus L.:

Plants with dark green foliage with a purple or pink colouration on the stem and inflorescence axis; dark reddish-purple glandular hairs on pedicel, calyx, filaments, ovary and style; flowers with purple or pale pink venation on the petals and with a pink or pinkish-white background ....... var. albus

Plants with pale green foliage and pale green colouration on the stem and inflorescence axis; green glandular hairs on pedicel, calyx, filaments, ovary and style; flowers with white petals, without venation, or with extremely feint grey-tinted venation var. albiflos

\section{Synonymic conspectus}

Dictamnus L., Sp. P1. 1: 383 (1753)

$\equiv$ Fraxinella Mill., Gard. Dict. Abr. ed. 4. (1754).

\section{Dictamnus albus var. albiflos (Rchb.) J.Compton \& Akeroyd, comb. nov.}

Basionym: "Dictamnus fraxinella Pers." var. albiflos Rchb., Fl. Germ. excurs. 2(2): 767 (1832). Holotype: "Südtyrol bei Botzen [Bolzano Prov.]: Elsm., [F.J.G.Elsmann] Mai-Juli." (B holo.) Note - no original material has been found at B or in the Reichenbach material at W, and the type is likely to have been destroyed in 1943 during the catastrophic bombing of the Herbarium in Berlin. A neotype has therefore been chosen and is designated here:

Type: Clifford Herbarium, "Fraxinella niveo flore Clusius Hist. 100 Dictamnus albus" (BM - neo.!) BM-000558741: https://data.nhm.ac.uk/object/921665d3-4cbd-4f3a-a227$15626296 f 803 / 1571875200000$

= Dictamnus albus L. var. leucopetalus Guss., Fl. Sicul. Syn. 2: 721 (1844). nom. illegit. (Art. 11.4)

Dictamnus albus var. albus L., Sp. Pl. 1: 383 (1753) Type: Herb. Clifford 161, Dictamnus 1 sheet A (BM000558738) (BM - lecto.!)

$\equiv$ Fraxinella alba (L.) Gaertn., Fruct. Sem. Pl. 1: 337 (1788).

三 Dictamnus odorus Salisb., Prodr. Stirp. Chap. Allerton 320: (1796) nom. illegit. (Art. 52.2(e))

三 “Dictamnus fraxinella Pers.”, Syn. Pl.1: 464 (1805) nom. inval. 
三Dictamnus solitarius Stokes, Bot. Mat. Med. 2: 485 (1812) nom. illegit. (Art. 52.2(e))

三Dictamnus suffultus Wallr., Linnaea 14(6): 569 (1841) nom. illegit. (Art. 52.2(e))

三Dictamnus albus var. purpureus Guss., Fl. Sicul. Syn. 2: 721 (1844).

$\equiv$ Dictamnus generalis E.H.L.Krause, in J. Sturm Deutschl. Fl. Abbild. ed. 2(7): 63 (1902) nom. illegit. (Art. 52.2(e))

= Fraxinella dictamnus Moench, Methodus Pl. 68 (1794) Lectotype (designated here): [Icon] Blackwell Cur. herbal t. 75 (1737).

= Dictamnus fraxinella Link, Enum. Hort. Berol. Alt. 1: 398 (1821).

= "Dictamnus fraxinella" Pers. var. rosea Rchb., Fl. Germ. excurs. 2(2): 767 (1832). nom. inval. (Art. 11.6)

= Dictamnus himalayanus Royle, Ill. Bot. Himal. Mts. 156 (1835) Lectotype designated here from syntypes: India, Himachal Pradesh, "Jumnotri peaks, [Garhwal] Lieutenant J.W.Stephens s.n.” (LIV - lecto.!) acc. 1952.121.3961. Syntypes: Kunawur [Himachal Pradesh, Kinnaur], $M r$ [R.] Inglis s.n.; Mirung [Himachal Pradesh, Moorang], Mr [R.] Inglis s.n., not located.

三 Dictamnus albus var. himalayanus (Royle) N.A.Winter, Bot. Mater. Gerb. Glavn. Bot. Sada R.S.F.S.R. 5: 159 (1924).

= Dictamnus obtusiflorus W.D.J.Koch, Syn. Fl. Germ. Helv., 1: 146 (1835) Lectotype designated here from among syntypes: Croatia, "bei Fiume [Rijeka], [F.W.] Noё” (B - lecto.!) B101092918, (WU, isolecto.) WU-0107678; Syntypes: Italy, “dem südlichen Tyrol [F.] Elsmann s.n.”, not located; Croatia, "Fiume im gebusch, Juni, Dr Nö̈ 1393 (B - syn.!) B101092919.

$\equiv$ Dictamnus fraxinella var. obtusiflorus (W.D.J.Koch) W.D.J.Koch, Syn. Fl. Germ. Helv. ed. 2(1): 1064 (1846).

$\equiv$ Dictamnus albus var. obtusiflorus (W.D.J.Koch) Nyman, Consp. Fl. Eur. 142 (1878).

= Dictamnus angustifolius G.Don ex Sweet, Brit. Fl. Gard. Ser. 2 vol. 1: t. 93 (1837). Lectotype (designated here): [Icon] Sweet, Brit. Fl. Gard. Ser. 2 vol. 1: t. 93 (1837). Note - no other original material is available.

$\equiv$ Dictamnus albus var. angustifolius (G.Don ex Sweet) Parl. Fl. Ital. 5(2): 364 (1872).

$\equiv$ Dictamnus albus subvar. angustifolius (G.Don ex Sweet) Rouy \& Fouc., Fl. France 4: 139 (1897).

= Dictamnus fraxinella var. caucasicus Fisch. \& C.A.Mey, Ind. Sem. Hort. Petrop. 6: 49 (1840) Type: Russia, North Caucasus, "In monte Beschtau" [Mt. Beshtau], 1829, C.A.Meyer 1780. (LE - holo.!) LE01064320.

三Dictamnus albus var. caucasicus (Fisch. \& C.A.Mey.) Rouy \& Fouc., Fl. France 4: 139 (1897).

$\equiv$ Dictamnus albus subsp. caucasicus (Fisch. \& C.A.Mey.) N.A.Winter, Bot. Mater. Gerb. Glavn. Bot. Sada R.S.F.S.R. 5: 159 (1924).

$\equiv$ Dictamnus caucasicus (Fisch. \& C.A.Mey.) Grossh., Flora Kavkaza 3: 20 (1932).

= Dictamnus fraxinella var. europaeus Fisch. \& C.A.Mey, Ind. Sem. Hort. Petrop. 6: 49 (1840). Lectotype (designated here): [Icon] N.J.Jacquin, Fl. Austr. 5: t. 428 (1778).

$\equiv$ Dictamnus albus var. europaeus (Fisch. \& C.A.Mey.) N.A.Winter, Bot. Mater. Gerb. Glavn. Bot. Sada R.S.F.S.R. 5: 157 (1924).

= Dictamnus sessilis var. acutiflora Wallr., Linnaea 14(6): 569 (1840) nom. inval. D. sessilis is nom. nud. (Art. 35.1) 
= Dictamnus dasycarpus Turcz., Bull. Soc. Imp. Naturalistes Moscou 15: 637 (1842). Holotype: "In pratis Dahuriae ad fluvia Schilka [Shilka] et Argun, v. gr. Prope pagum Biankina. Floret Junio, N.Turczaninow s.n.”. (LE)

$\equiv$ Dictamnus fraxinella var. dasycarpus (Turcz.) Regel, Mem. Acad. Imp. Sci. St. Petersburg, ser. 7, 4(4): 40 (1862).

$\equiv$ Dictamnus albus subsp. dasycarpus (Turcz.) N.A.Winter, Bot. Mater. Gerb. Glavn. Bot. Sada R.S.F.S.R. 5: 159 (1924).

三Dictamnus albus var. dasycarpus (Turcz.) Liou \& Y.H.Chang, Fl. Pl. Herb. Chin. Bor.Or. 6: 24 (1977).

= Dictamnus fraxinella var. purpureus Guss., Fl. Sicul. Syn. 1: 463 (1843).

= Dictamnus gymnostylis Steven, Bull. Soc. Imp. Naturalistes Moscou 29(1): 333 (1856). Lectotype (designated here): Ukraine,"In silvaticis frequens, idem in campis ad rivum Kaltschik [Kalchik] in Maeotidem [Asov] influentem" Steven s.n. (H - lecto.!), C.189867.

三Dictamnus albus subsp. gymnostylis (Steven) N.A.Winter, Bot. Mater. Gerb. Glavn. Bot. Sada R.S.F.S.R. 5: 159 (1924).

= Dictamnus fraxinella var. macrophylla Schur (Dictamnus obtusiflorus W.D.J.Koch, Syn. Fl. Germ. Helv., 1: 146 (1835)), Enumeratio plantarum Transsilvaniae 141 (1866) Lectotype: Romania, Brasov, Hangstein bei Kronstadt [Brasov] auf kalk $2000 \mathrm{ft}$. "Im Pfarrgarten bei Stolzenburg [Slimnic] 26 June 1854, P.J.F.Schur s.n.” (LW - lecto.!), LW205721.

= Dictamnus fraxinella var. microphylla Schur (D. microphyllus Schur), Enumeratio Plantarum Transsilvaniae 141 (1866) Holotype: Romania “Auf Kalkfelsen des Ecsem-Teteje [On lime rock of the Ocsem Teteje [Ecem peak], Transylvania] July, P.J.F.Schur s.n.” (LW - holo.!), LW205722.

= Dictamnus albus var. lanceolatus Pasq., Ann. Accad. Aspir. Naturalisti ser 3(2): 111 (1862) Type: Italy, "Primae Calabrias Ulterioris prope Rosarno [Reggio Calabria], solo arenoso inter dumos. Floret Maio, G. Pasquale s.n.” (FI - holo.! ); FI-105895 (FI - iso.!) FI-105895a.

= Dictamnus hispanicus Webb ex Willk. Suppl. Prodr. Fl. Hispan. 263 (1893). Lectotype designated here from syntypes: Spain Murcia Prov., "in Monte Mugrón prope Albacete in pascuis, alt. 1200-1400 m. [Pietro] Porta et [Gregorio] Rigo Plantae Hispaniae 460, Junio, 1890" (WU - lecto.!) WU-0107677. Syntypes: Spain, Castelló Prov., "Sierra del Monte Major, pineta prope Segorbe, [C.] Pau s.n." (MA - syn.!) MA-426450; Catalunia Prov. "Sierra de Monsant. Pujol s.n."; "Sierra de Espedán Reverchon s.n., 1891"; "Sierra del Monte Major, pineta prope Segorbe, Pau s.n."; "Sierra de El Toro [C.], Pau s.n.”; "Rambla de Elche, Lacaita s.n. 1884"; Murcia Prov., "in Monte Mugrón prope Albacete alt. 1200-1400 m. Porta \& Rigo 460, 1891"; Alméria Prov. "Sierra de Maria, Wilkomm s.n.” (COI).

= Dictamnus macedonicus Borbás, Természetrajzi Füzetek 19(3/4): 352 (1896). Holotype: Greece, Macedonia, "Kortiath [Mt. Chortiátis] ad Banjo [historic springs that supplied water to Thessaloníki], in monte granitico, June 1835, in Herb. Mus. Nat. Budapest, legit Hinke s.n." Note: Many specimens at BP from the herbarium of Vincze Borbás were destroyed during WW2.

= Dictamnus levistylus Borbás, Természetrajzi Füzetek 19(3/4): 356 (1896). Syntypes:

"Romania ad Portam ferream" [River Danube, Iron Gates gorge]; Austria, "Vindobonae [Vienna] [F.] Kováts 317”, probably destroyed during WW2. 
= Dictamnus longifrons Borbás, Természetrajzi Füzetek 19(3/4): 356 (1896). Holotype: Bosnia, "ad Czeniza [Zenica], Herb. Mus. National Budapest, Sendtner s.n.” (BP?). Paratypes: Krym "Herb. [Árpád von] Degen e Tauria"; Serbia, "Neusatz [Novi Sad], June 1895. M.Wetschky 19", probably destroyed during WW2.

= Dictamnus albus subvar. latifolius Rouy \& Fouc., Fl. France 4: 139 (1897).

= Dictamnus albus var. gynodynamicus Beck, Repert. Spec. Nov. Regni Veg. 17(29): 450 (1921). Lectotype selected from a specimen in the Beck herbarium grown from a cultivated plant in the Charles University Botanic Garden, Prague: Czech Republic, Prague, "et in horto botanico culta, June 1914”, (PRC - lecto.!) PRC-455665; syntype: "Bohemia prope Karlstein [Karlstejn] G.Beck s.n." (not found).

= Dictamnus albus subsp. turkestanicus N.A.Winter, Bot. Mater. Gerb. Glavn. Bot. Sada R.S.F.S.R. 5: 158 (1924). Syntypes: Kazakhstan, "Herb. [C.F. von] Ledebour, circa Nor-Saissan [Lake Zaysan], flor.”; Kazakhstan, "ad fl. Cocksu [Koksu river] 4-5000 ft supra mare, A.Regel s.n.”; Kazakhstan, “Alatau Transiliensis [Trans-Ili Alatau Mts], in angustiis Butakov [Butakovka gorge] 21 June 1909, V.I.Lipsky s.n.”; Kazakhstan, “dist. oppidum Vernyj [Almaty], flor.” (LE).

= Dictamnus albus var. kansuensis N.A.Winter, Bot. Mater. Gerb. Glavn. Bot. Sada R.S.F.S.R. 5: 158 (1924). China, "crescit in Prov. Kansu" [Gansu].

= Dictamnus albus subsp. turkestanicus var. bucharicus N.A.Winter, Bot. Mater. Gerb. Glavn. Bot. Sada R.S.F.S.R. 5: 159 (1924) Type: Tajikistan, Tirkoni, Pamir Alai Mts. "Bukharsk vlad. (Bukhara region] Kulyabskoye bekstvo [Kulob, Khatlon Prov.] surroundings of Tirkoni village in the Tirkoni river valley, 4 May 1910. D.A.Divnogorskaya 313" (LE - lecto.!), LE00050990; (LE - isolecto.!) LE00050991.

$\equiv$ Dictamnus tadshikorum Vved., Flora of the USSR 14: 230 [176] (1949). nom. inval. (Art. 26.2)

= Dictamnus dasycarpus var. velutinus Nakai, J. Jap. Bot. 13(7): 480 (1937). Holotype: North Korea “Kanhoku Prov. [Hamgyong], Seisin [Chongjin], 17 June 1909, T.Nakai s.n.” (TI?)

$\equiv$ Dictamnus dasycarpus f. velutinus (Nakai) W.Lee, Lineamenta Florae Koreae 640 (1996).

= Dictamnus caucasicus var. angustifolius N.A.Winter, Flora Kavkaza 6: 54 (1950). Holotype: Dagestan, “circa oppidum Temirchan-Schura [Buynaksk], leg. A.Becker 66. 1870 (LE - holo.!) LE01064329.

= Dictamnus caucasicus var. grandidentatus N.A.Winter, Flora Kavkaza 6: 54 (1950). Type: not located.

\section{Conclusion}

Dictamnus albus L., a handsome, variable species of wide geographical distribution that has generated extensive synonymy, has both purple- and white-flowered variants. Linnaeus's type (var. albus) has purple-streaked flowers, and although he was familiar with both flower colours and alluded to them in Species Plantarum, he never gave a name to the white-flowered variant, which also has pale green foliage. The invalid name "var. purpureus", widely used in horticulture, is merely a synonym of var. albus. White-flowered plants, uncommon in the wild but more widespread in cultivation, should be called Dictamnus albus var. albiflos (Rchb.) J. Compton \& Akeroyd. We have designated a neotype from Linnaeus's own herbarium (BM). 
Acknowledgements: Many thanks to John McNeill (E), Nicholas Turland (B) John Wiersema (US) and Werner Greuter (B) for our discussions on the nomenclatural complexities of this species and for their sage advice and recommendations. Also many thanks to those who located herbarium specimens for us: Hans Walter Lack and Robert Vogt (B), Jacek Wajer (BM), Zoltán Barina (BP), Mihai Puşcaş (CL, type material not found), Chiara Neppi and Anna Donatelli (FI), Larisa Raenko, Irina Illarionova and Ivan Tatanov (LE), Donna Young (LIV), Eva García Ibáñez (MA), Patrik Mráz and Viera Mrázová (PRC), Christian Bräuchler (W), Walter Till and Dieter Reich (WU) and Ari Taponen $(\mathrm{H})$ with special thanks for aiding with the translation of Russian annotations. Thanks too to Andrew Radice for checking our translations of quotes from the botanical Latin of pre-Linnaean authors; and to Bob Gibbons and Hardy's Cottage Garden Plants, Whitchurch, Hampshire, UK for use of the photographs in Figs 12.

\section{REFERENCES}

1. Bauhin, C., 1623, Pinax theatri botanici Caspari Bauhini Basileensis, Ludovici Regis, Basel.

2. Blackwell, E., 1737, A Curious Herbal, 1: t. 75, Samuel Harding, London.

3. Candolle, A.P. de, 1824, Prodromus systematis naturalis regni vegetabilis, pt. 1, Treuttel and Würtz, Paris.

4. Clusius, C., 1601, Rariorum plantarum historia, Plantin apud Joannem Moretum, Antwerp.

5. Dodoens, R., 1563, Cruijdeboeck, Jan van der Loe, Antwerp.

6. Jarvis, C.E., Barrie, F.R., Allan, D.M., Reveal, J.L., 1993, A list of Linnaean generic names and their types, Regnum vegetabile, 127: 1-100.

7. Linnaeus, C., 1738, Hortus Cliffortianus, Amstelaedami [Amsterdam].

8. Linnaeus, C., 1748, Hortus Upsaliensis, Holmiae [Stockholm], Laurentius Salvius.

9. Linnaeus, C., 1749, Materia Medica, Holmiae [Stockholm], Laurentius Salvius.

10. Linnaeus, C., 1753, Species Plantarum, ed. 1. Holmiae [Stockholm], Laurentius Salvius.

11. Mabberley, D.J., 2017, Dictamnus in Mabberley's Plant Book, $4^{\text {th }}$ ed.: 292, Cambridge University Press.

12. Persoon, C.H., 1805, Synopsis plantarum sue Enchiridium botanicum 1: 464, Carol. Frid. Cramerum, Paris; J. G. Cottam, Tubingae [Tubingen].

13. Reneaulme, Paul de, 1611, Specimen historiae plantarum, Hadrianum Beys, Paris.

14. Royen, A. van, 1740, Florae Leydensis Prodromus, Samuelen Luchtmans, Lugduni Batavorum [Leiden].

15. Ruel, J., 1552, Dioscorides De Medicinali Materia [De Materia Medica] libri sex (book 3), Ioanne Ruellio Suessionensi [Jean Ruel, Soissons, France], Lugduni [Leiden], Balthazarum Arnolletum, First ed. 1516.

16. Sauvages, F.B. de la Croix de, 1751, Methodus foliorum, 's Gravenhage.

17. Stearn, W.T., 1993, Stearn's dictionary of plant names for gardeners, Revised edition, Cassell Ltd, London.

18. Tournefort, J.P. de, 1700, Institutiones rei herbariae edition altera 1. Paris.

19. Townsend, C.C., 1967, Dictamnus L. In: Davis, P.H., Cullen, J., Coode, M.J.E., (eds.), Flora of Turkey and the East Aegean Islands 2: 506, University Press, Edinburgh.

20. Townsend, C.C., 1968, Dictamnus L. In: [Eds. Tutin, T.G., Heywood, V.H., Burges, N.A., Moore, D.M., Valentine, D.H., Walters, S.M., Webb, D.A., (eds.), Flora Europaea 2: 229, Cambridge University Press.

21. Turland, N.J., Wiersema, J.H., Barrie, F.R., Greuter, W., Hawksworth, D.L., Herendeen, P.S., Knapp, S., Kusber, W-H., Li, D-Z., Marhold, K., May, T.W., McNeill, J., Monro, A.M., Prado, J., Price, M.J., Smith, G.F., (eds.), 2018, International Code of Nomenclature for algae, fungi, and plants (Shenzhen Code) adopted by the Nineteenth International Botanical Congress Shenzhen, China, July 2017. Regnum Vegetabile 159. Glashütten: Koeltz Botanical Books. https://doi.org/10.12705/Code.2018

22. Willdenow, C.L., 1799, Caroli a Linné Species Plantarum, Berolini [Berlin], G. C. Nauk.

\section{DENUMIREA CORECTĂ A VARIETĂȚII CU FLORI ALBE DE DICTAMNUS ALBUS L. (RUTACEAE)}

(Rezumat)

În această lucrare investigăm utilizarea denumirii lineene Dictamnus albus L. care se deosebeşte de specia Origanum dictamnus L., un labiat endemic în insula Creta. Denumirea lineeană a acestei specii nu face referire la culoarea florilor, ci s-a bazat pe numele medicinal pentru rădăcinile albe ale plantei. Datorită faptului că specimenul 
tip descris de Linné are tulpini purpurii și flori cu dungi purpurii, am publicat numele Dictamnus albus var. albiflos (Rchb.) J. Compton \& Akeroyd, comb. nov. pentru plantele cu flori albe. Acest caracter deosebește aceste plante de varianta tipică mult mai răspândită, cunoscută mai ales în literatura horticolă, drept $D$. albus var. purpureus, o denumire invalidă. De asemenea, am desemnat un neotip pentru var. albiflos şi un lectotip pentru nouă dintre denumirile din sinonimia D. albus var. albus: Dictamnus albus var. bucharicus N.A.Winter, Dictamnus albus var. gynodynamicus Beck, Dictamnus angustifolius G.Don ex Sweet, Dictamnus fraxinella var. europaeus Fisch. \& C.A.Mey., Dictamnus fraxinella var. macrophylla Schur, Dictamnus gymnostylis Steven, Dictamnus himalayanus Royle, Dictamnus obtusiflorus W.D.J.Koch și Fraxinella dictamnus Moench.

Received: 18.11.2019; Accepted: 20.11.2019. 